\title{
Assessing Ecological Status of Transitional and Coastal Waters; Current Difficulties and Alternative Approaches
}

\author{
Ricardo Beiras * \\ Department of Ecology and Animal Biology, University of Vigo, Galicia, Spain
}

The environmental monitoring strategy termed ecosystem-based approach (EBA) underlines the obvious benefits of managing natural resources on a holistic level, and it is particularly invoked for the rational and sustainable management of aquatic resources. However, when coming to implement EBA into monitoring schemes, such as those derived from the implementation of the European legislation concerning water quality, difficulties inherent to the complex and dynamic nature of ecosystems arise, including (i) identify appropriate, relevant and easily measurable indicators of ecosystem integrity, and (ii) combine the heterogeneous information gathered at the different levels of organization

OPEN ACCESS

Edited by:

Rathinam Arthur James, Bharathidasan University, India

Reviewed by:

Periyadan K. Krishnakumar, King Fahd University of Petroleum and Minerals, Saudi Arabia Riaan Van Der Merwe, The Petroleum Institute, United Arab Emirates

*Correspondence: Ricardo Beiras rbeiras@uvigo.es

Specialty section: This article was submitted to Marine Pollution, a section of the journal Frontiers in Marine Science

Received: 25 January 2016 Accepted: 19 May 2016 Published: 02 June 2016

Citation:

Beiras R (2016) Assessing Ecological Status of Transitional and Coastal Waters; Current Difficulties and Alternative Approaches. Front. Mar. Sci. 3:88 doi: 10.3389/fmars.2016.00088 included in an ecosystem into a simple and practical decision-making scheme. The first kind of difficulties maybe partially overcome by implementing monitoring schemes which take into account the hierarchical nature of ecosystem processes and did not neglect the use of indicators at low levels of biological organization, including ecotoxicological biomarkers and bioassays. Secondly, the integration of the monitoring results into a practical decision-making scheme can best be achieved by using non-metric multivariate analysis, which is especially suitable for data bases including different metrics, and allows the processing of variables showing non-monotonic response to human stress, from molecular biomarkers to community indices. The difficulties inherent to the current rigid scheme of water quality assessment heavily based on ratio-to-reference univariate indicators and arbitrary reference values and class boundaries for each single indicator are illustrated with a case study in the Minho estuary (NW Iberian Peninsula). The classification of aquatic ecosystems into discrete categories of ecological status can best be achieved by combining observations at different levels of biological organization, from molecular biomarkers to community traits, with explicative physicochemical and hydromorphological elements, and by using non-metric multivariate analysis techniques.

Keywords: biological monitoring, water quality, ecosystem-based approach, biomarkers, bioassays

\section{INTRODUCTION}

When in 1935 the English botanist Sir Arthur Tansley coined the term "ecosystem" to refer to the assemble of biological and physical elements of a living system, within a similar conceptual framework that would inspire von Bertalanffy's general systems theory, he could hardly imagine that just 60 years later his highly theoretical concept would be reflected in important pieces of 
legislation and enforcing laws. The so-called ecosystem-based approach (EBA) is currently defined by the UN Convention on Biological Diversity as "a strategy for the integrated management of land, water, and living resources [...] based on the application of appropriate scientific methodologies focused on levels of biological organization which encompass the essential processes, functions and interactions among organisms and their environment" (CBD, 2016). The EBA was embraced as the way forward to tackle different environmental issues, from conservation of the biodiversity (Schei, 1999) to management of the marine resources (Arkema et al., 2006; Morishita, 2008). Regarding the latter, EBA was invoked by Canada's Oceans Act in 1997, by Australia's Ocean Policy in 1998, and by the two USA Commissions for marine policies (the nongovernmental Pew Oceans Commission and the congressionally mandated US Commission on Ocean Policy), and the resulting Oceans 21 bill in the early 2000s (Christie, 2006).

In Europe, with the turning of the century the Water Framework Directive (WFD) (Directive 2000/60/EC) was adopted, and that legislative initiative triggered a cascade of environmental regulations, including the marine environmental policies (Directive 2008/56/EC), and the environmental quality standards for priority pollutants in continental and marine waters (Directive 2008/105/EC and Directive 2013/39/EU). The first purpose stated in the WFD was "to establish a framework which [...] prevents further deterioration and protects and enhances the status of aquatic ecosystems."

The WFD targeted the ambitious goal of achieving good ecological and chemical status in all natural surface water bodies of the EU by 2015, and designed the river basin districts as the units for management of the aquatic ecosystems, including not only the river basins but also the associated groundwaters and coastal waters. The strategy implemented to achieve this goal was based on 7-years cycles of environmental assessment intended to identify water bodies failing to achieve good status, and take the needed remediation measures to prevent deterioration and improve, if necessary, that status for the next assessment cycle. In this aspect, the methodology reflected in the WFD stems from a strategy of environmental assessment known as the DPSIR (driverspressures-states-impacts-responses) framework. According to that there is a circular chain of causal links starting with "driving forces" (human activities, economic sectors) through "pressures" (emissions, waste) to "states" (physical, chemical, biological) and "impacts" (on ecosystems and human health), hopefully leading to political "responses" intended to ameliorate the impacts (environmental protection regulations) by modifying the driving forces.

The need to identify the specific anthropogenic pressures causing less than good status, and to describe the quantitative relationship between the level of pressure and the deleterious ecological effect is essential to plan effective restoration measures, and this is central to achieve the WFD goals. However, some difficulties have arisen from the current approach, which in fact delayed the assessment of the quality status (European Environment Agency, 2012), and the ambitious goal of the Directive was currently not achieved.

\section{TOWARDS A MORE HOLISTIC SCHEME OF ENVIRONMENTAL MONITORING}

The DPSIR proposes a rather long causal chain of 5 links, with some distinctions (driver vs. pressure, stress vs. impact) not useful from a monitoring standpoint (see below). The WFD in turn proposed a closed and compartmentalized set of biological, physic-chemical-, and hydro-morphological elements to be measured for the "ecological status" assessment, and a separate set of chemical measurements for the "chemical status" assessment. The separations lack scientific grounds. For example concentrations of priority substances (sensu Directive 2013/39/EU) are considered to assess the chemical status, whilst concentrations of other similar substances not included in the list of the Directive are considered for the ecological status. Besides, since the tolerable limits for each indicator depends on the ecological characteristics of the water body (typology sensu WFD), a titanic effort of taxonomic classification of aquatic ecosystems (types) and adoption of type-specific reference conditions and class boundaries is still in progress, an effort particularly complicate for marine ecosystems, where a myriad of natural sources of variability determine the composition of communities and abundance of species (see below).

The background for a more holistic, less arbitrary, and conceptually simpler scheme of assessment of the human impact on the environment has been provided by the lifetime work of ecologist Eugene Odum. Working on solid thermodynamics foundations, Odum described ecosystems as far-from equilibrium open systems where processes at lower levels of organization are constrained by those at higher levels. Thus major functional processes (e.g., primary production) of the system as a whole should be examined, since analysis of these complex systems one piece at a time does not provide correct insight into their functioning (Odum, 1989). According to this systemic approach, persistence of an open system despite changes in boundary conditions depends on the maintenance of functional integrity whilst processing throughputs of energy and materials (Tett et al., 2013). Therefore environmental monitoring of ecosystem status should also follow this systemic and top-down hierarchical approach rather than promote fragmentation into an excessive number of discrete indicators individually assessed according to prefixed class boundaries.

However, the search for functional traits with practical value for routine monitoring had limited success, since functional attributes of ecosystems are difficult to capture in simple parameters. In addition, the fundamental properties of ecosystems are dynamic in nature, and thus not easily measurable in discrete monitoring campaigns (Odum and Cooley, 1980). Still, many attempts have been made to find measurable variables useful as quantitative 
indicators of anthropogenic perturbation affecting attributes related to ecosystem services. These include: reduction in richness, diversity (particularly functional diversity) and equitability indices of the community, reduction in the mean size of dominant species, increase in the prevalence of parasites, increase in the investment in mechanisms of defense, excessive primary production, increase in the production/biomass ratio, increased levels of inorganic $\mathrm{P}$ and $\mathrm{N}$, increased community respiration, or increase in the autotrophs/decomposers proportion of energy flow (Odum, 1985; Gray, 1989; Costanza et al., 1997; Vogt et al., 1997; Elliot et al., 2007).

Industrialized countries focus their activities on maximizing the outputs in production processes. This causes acceleration in the flows of energy orders of magnitude above those in natural ecosystems, and an unbalance in the cycles of matter that leads to increased rates of consumption of natural resources and emissions of waste. As advocated by Odum almost three decades ago (Odum, 1987) environmental management should address inputs (consumption) rather than outputs (production), seeking maximum efficiency (production divided by consumption, both in energy units) rather than maximum yield. More specifically, environmental managers need information in order to plan remediation actions intended to decrease consumption of natural resources and control emissions of waste (Figure 1). This information must stem from sounded environmental monitoring programs. First, there is no reason to restrict environmental monitoring to the state (status sensu WFD) of the ecosystem; a more integrated approach should combine monitoring impacts (effects measured in the ecosystems using variables such as diversity or water quality traits) with monitoring pressures (causes of those effects, which can be measured and controlled before emissions are made or resources are extracted). This combination is well-known in aquatic environments were both discharges and receiving waters must be monitored to provide a combination of effectiveness and environmental relevance. Secondly, chemical and biological monitoring tools must be integrated since they provide complementary pieces of information, and not separated in independent assessments of ecological and chemical status. A specific biomarker, for example induction of vitellogenin in male fish, may alert from the presence in the environment of certain undesirable substances, and prompt the analytical search for, in this case, estrogenic chemicals in the water.

A complete EBA such as that depicted in Figure $\mathbf{1}$ will thus include monitoring extraction of resources, stocks assessment for both non-renewable and renewable (living) resources, monitoring emission of pollutants, levels of pollutants in the environment, and their biological effects on ecosystems and human health. Prioritization of remediation actions would thus depend on the magnitude of the deleterious effects quantified by means of the integrative monitoring programs, and the costeffectiveness of the implemented actions can be evaluated at the light of the results provided by the next assessment cycle. In this paper I will focus on the environmental pollution monitoring aspects.

\section{CONSIDERING THE HIERARCHICAL AND DYNAMIC NATURE OF ECOSYSTEMS}

\section{"Biological," "Chemical," and "Hydromorphological" Quality; An Inverted Hierarchy}

As well-known in basic ecology, the distribution, and abundance of species in unexploited ecosystems depends on environmental conditions and resources. The abiotic physic-chemical environmental factors such as temperature, $\mathrm{pH}$, salinity, light, bottom texture, nutrient availability, etc. place limits to the proliferation of organisms and shape the community structure. The methodology reflected in the WFD for the assessment of the "ecological status" contravenes this basic principle and proposes a tiered scheme where biological elements are first considered, chemical elements are assessed only if biological elements are good, and hydromorphological elements are considered only if both biological and chemical elements do not depart from reference (i.e., pristine) conditions. The evaluation scheme thus begins by the more complex levels of organization and progresses downwards toward the physical elements, rather than following the usual hierarchy in line with ecological theory, beginning by the physical factors that determine the distribution and abundance of the organisms, and thus the community structure. Moreover, the scheme seems unpractical since hydromorphological alterations are far easier (and less costly) to monitor than changes in community structure or ecosystem functioning, and it is highly unlikely that strong anthropogenic physical alterations will not have an impact on the biotic component of the ecosystems.

\section{Lower Levels of Biological Organization are Ignored}

Concerning the biological component of the ecosystems, the current scheme of assessment of ecological status relies heavily on community indices, and ignores biological responses at lower levels of biological organization, which can give insight into the causal agents of impact and early warning signals of anthropogenically driven alteration. A trade-off between the ecological relevance of the community indices and the sensitivity of molecular methods, which are also useful for the identification of mechanisms and quantitative dose-response relationships, should be achieved. In addition, the dynamic nature of ecosystems, with random fluctuations, and natural cycles, demand rapid and cost-effective assessment tools, a requirement that community indices do not meet.

Molecular and physiological biomarkers and ecotoxicological bioassays provide rapid, sensitive, and inexpensive tools of environmental assessment particularly suitable for the classification of the ecological status of surface waters (reviewed by Martínez-Haro et al., 2015; see also Allan et al., 2006). Biomarkers have been already used as assessment tools in regulatory environmental monitoring networks such as US Geological Survey program for Biomonitoring of Environmental Status and Trends (BEST), and the OSPAR Convention Joint Assessment, and Monitoring Program (JAMP). 


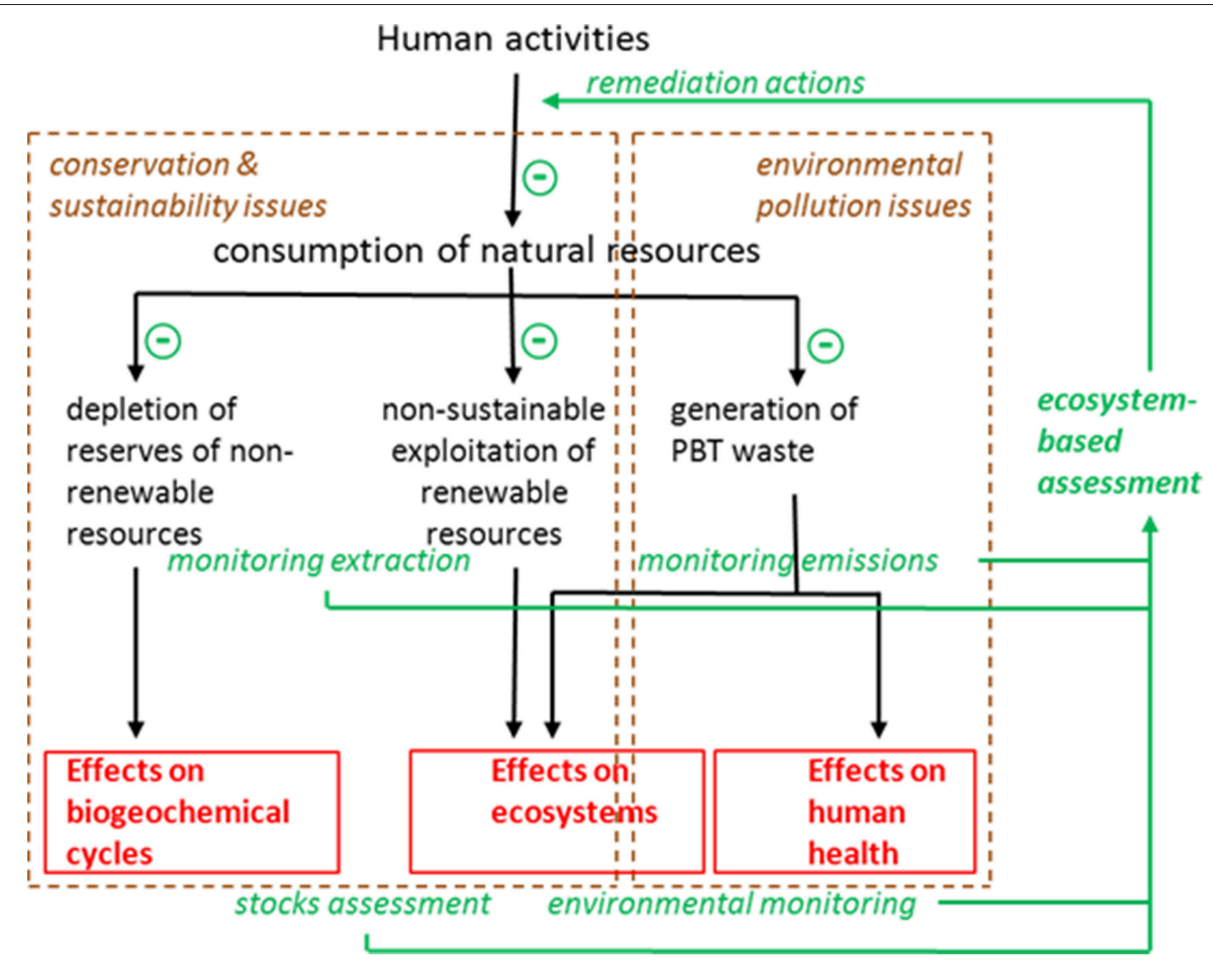

FIGURE 1 | Scheme of a holistic ecosystem-based assessment (EBA) intended to manage the environment in order to avoid depletion of non-renewable resources, non-sustainable exploitation of renewable resources, and environmental pollution. Notice that remedial actions are planned according to the information gathered in the monitoring programs that include both monitoring the levels of pressures (extractions, emissions; i.e., causes) and monitoring the levels of impact (effects) on ecosystem structure, functioning, and human health.

Therefore, it seems advisable in marine environmental monitoring to combine community indices with other biological tools such as ecotoxicological biomarkers and bioassays capable to provide early warning signals of potential ecological damage. The main current drawback for their application at a broader scale seems to be the need for a clear reference system based on comprehensive interlaboratory quality-assurance programs (Sanchez and Porcher, 2009).

\section{The WFD Proposed a Chemical Status Assessment Based in Monitoring Water Only}

The original approach for chemical monitoring sensu WFD surprisingly ignored the scientific consensus achieved by marine environmental studies and the so derived monitoring tools adopted by the institutions in charge of the assessment of marine pollution. This consensus includes two notions very relevant for practical monitoring. First, sediment is a better descriptor of chemical status than water, since coastal and estuarine sediments act as sink for chemical pollutants, showing concentrations orders of magnitude higher than water for persistent pollutants, and those concentrations are far more stable and independent of climatic factors and episodic spillages, providing more robust assessment data. For certain organic priority pollutants chemical monitoring in water is also limited by the availability of analytical methods with the required limits of detection, the lack of certified reference materials with similar matrices, and the need for ECwide inter-laboratory testing exercises (Coquery et al., 2005).

Secondly, sedentary organisms such as bivalve mollusks can be used as biomonitors of chemical pollution, providing a more ecologically relevant signal since they accumulate the bioavailable fraction only, and serve as an indication of the risk of transfer of those pollutants to higher trophic levels, including humans. Marine mussels in particular are ubiquitous, easy to collect, and they accumulate waterborne pollutants at high concentrations in their tissues, due to the apparently low metabolic biotransformation capability of these invertebrates (Livingstone, 1991).

In US the Mussel Watch program initiated by the USEPA in the period 1976-78, and continued by the NOAA from 1986 to date, is based on yearly collection of oysters (Crassostrea virginica) and mussels (Mytilus spp and Dreissena spp) in 300 sites from the Atlantic, Pacific, and Great Lakes coasts, and measures more than 140 chemical contaminants, including metals and metalloids, PCB, PAH, butyltins, and organochlorine pesticides. These tools allowed identification of geographical patterns and temporal trends of chemical pollution for metals, hydrocarbons, and organochlorine compounds. For example, the commercial, military and recreational boating activity in the San Diego Bay caused elevated butyltin contamination, but several of its sites showed in 2008 a decreasing trend, following the 
universal ban of TBT at the beginning of the century. In contrast, the elevated levels of cadmium found in the Chesapeake Bay and associated to industrial wastewater discharge and urban stormwater runoff are not decreasing despite years of restoration efforts (Kimbrough et al., 2008).

In Europe, the OSPAR Commission requires that contracting parties undertake at regular intervals joint assessments of the quality status of the marine environment in order to evaluate the effectiveness of the measures taken for the protection of the marine environment and identify priorities for action. OSPAR JAMP includes since 1997 measurements of chemicals in sediments and biota, mainly mussels, and oysters (OSPAR Commission, 1997).

\section{USING MULTIVARIATE ANALYSIS TO INTEGRATE HETEROGENEOUS INFORMATION INTO A SIMPLE DECISION-MAKING SCHEME}

Multivariate analyses are specially indicated for the treatment of heterogeneous data sets as those generated from ecological studies (Gotelli and Ellison, 2004). Multidimensional scaling is a non-metric ordination method particularly useful when assumptions to conduct metric techniques such as PCA are unwarranted (Landis et al., 1997). MDS is robust against background noise from random variables, and applicable to "shallow" matrices, such as those obtained in monitoring campaigns where a large number of variables are measured in a relatively small number of sites (Matthews et al., 1995). MDS followed by cluster analysis allows objective classification of sites into a predefined number of environmental status categories, as required by current legislation, according to a more objective and practical scheme (Beiras and Durán, 2014).

The current scheme of assessment for classification of ecological status requires for each individual indicator to present a monotonic and linear relationship between the value of the indicator and the level of anthropogenic pressure (Figure 2A). However, many useful indicators at different levels of biological organization, including community traits, provide yes-or-not or bell shaped responses to anthropogenic pressures (see Figures 2B,C). These quantitative patterns of response are not useful within the current scheme of assessment based on multiple univariate linear responses, but they can be integrated into a more holistic assessment scheme as long as multivariate statistical methods were employed.

Molecular biomarkers such as enzymes whose activity is induced by exposure to environmental pollutants frequently present a bell-shaped response to the concentration of pollutant. This is the case of the cytochrome P-450 1A enzymes, which are induced by molecules that bind to the aryl hydrocarbon receptor, such as PAHs, dioxins and dioxin-like molecules. The induction can be quantified by the ethoxyresorufin-O-deethylase (EROD) assay, widely used both in vivo and in vitro as a marker for exposure to marine pollutants (e.g., Burgeot et al., 1994). The EROD activity increases as the environmental level of the above mentioned pollutants increase, but above a threshold that depends on the potency of the inducer competitive inhibition by the inducer itself causes a decrease in the response, resulting in a bell-shaped pattern (Figure 2B; see also Petrulis and Bunce, 1999). On the other end of biological organization, species richness, and other community traits also show bell-shaped responses to anthropogenic pressures, as acknowledged in the original Pearson and Rosenberg (1978) paradigm for the effect of organic enrichment on benthic communities (Figure 2C).

Multivariate ordination methods such as non-metric MDS (suitable for heterogeneous databases with different metrics and not normally distributed variables) followed by clustering analysis allow objective classification of sites into discrete categories of ecological status on the basis of the overall environmental information obtained in the monitoring campaigns as long as the data set encompasses the full range of environmental conditions, from unaltered to impacted (Beiras and Durán, 2014). This would be preferable to the current strategy that uses multiple univariate measurements of different metrics that must then be combined according to the debatable "one out all out" rule, which assigns less than good status on the basis of a single excedance in the quality measurements.

\section{SPECIFIC DIFFICULTIES IN TRANSITIONAL WATERS: THE TEAM MINHO CASE STUDY}

According to the European Environment Agency (2012), the classification of status across European surface waters is particularly delayed for transitional water bodies. In 2012 the Team Minho Project (TMP), supported by EU FEDER funds, conducted a broad assessment of the chemical and ecological status of the water bodies from the Minho estuary, which makes the Northern border between Spain and Portugal. The main objective was to harmonize the methodologies used by both administrations in order to provide a common classification for these international water bodies. The TMP proposed, on the basis of the gathered ecological information, a reduction from four to three water bodies and a change of typology from transitional to fluvial of the resulting inner water body, more coherent with the hydrological, faunistic, and floristic characteristics. Upper limit of the salinity range and distribution of typically marine (e.g., Mytilus galloprovincialis) or typically fluvial (e.g., Corbicula fluminea) species provided particularly useful and coherent information. The reassignment of typologies allowed the use of more adequate reference conditions and class boundaries compared to previous efforts from the Spanish (CHMS) and Portuguese (APA) hydrographic authorities, which had classified the four water-bodies under a common typology. Despite that, the results (Table 1) illustrate the difficulties to implement the current scheme of assessment to estuarine environments.

The chemical status of the estuarine water bodies was classified by the TMP as good, on the basis of the concentrations of the priority pollutants measured, at the light of both the applicable standards (Directive 2013/39/EU for Cd, Pb, Hg, Ni, TBT, Nap, Ant, Flu, BaP, DDTs, PBDEs, nonylphenols, and octylphenols) and additional, internationally accepted, water quality criteria (US-EPA for $\mathrm{Cu}, \mathrm{Cr}$, and PCBs). This was consistent with the 


\section{A}

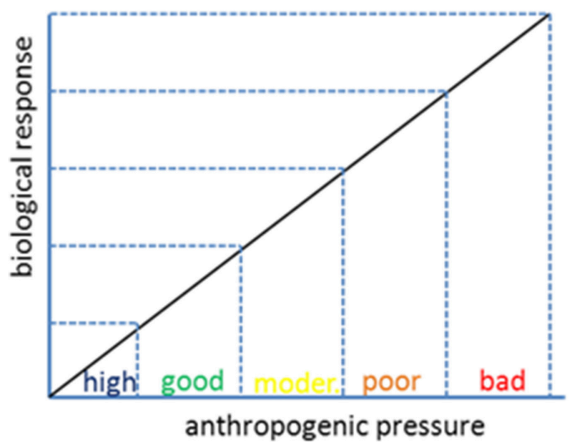

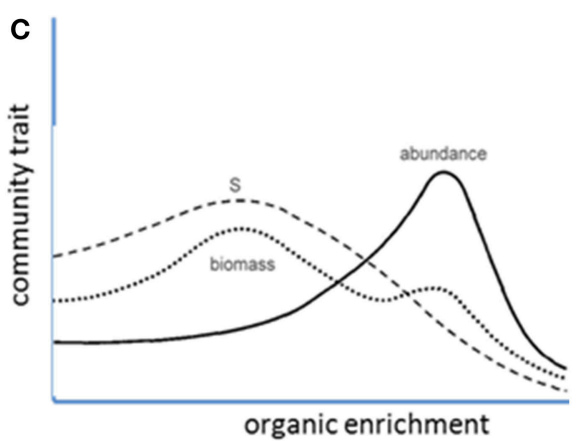

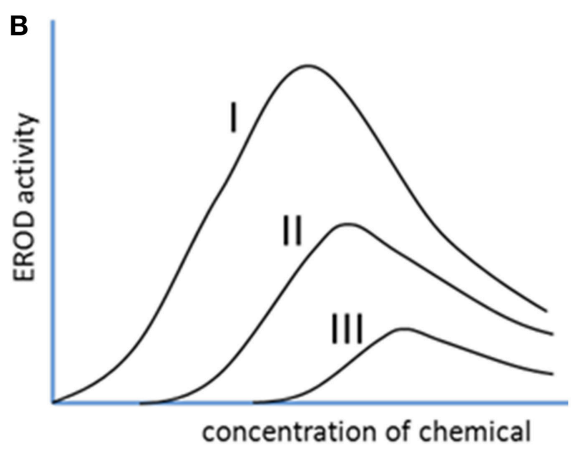

FIGURE 2 | Quantitative patterns of biological response to anthropogenic pressures. A linear or linearizable response (A) is assumed in the current scheme of use of ratio-to-reference values for classification of ecological status of water bodies into one of five categories (high, good, moderate, poor, or bad). However, bell-shaped responses are frequent at different levels of biological organization, from molecular biomarkers to community indices. (B) Shows EROD activity vs. concentration of three chemicals of decreasing potency from Petrulis and Bunce (1999). (C) Shows the well-known Pearson and Rosenberg (1978) paradigm according to which species richness in benthic communities is maximum at intermediate levels of organic pollution.

previous CHMS and APA classifications except for the high levels of nonylphenol found by APA in the outer water body. The temperature, salinity, $\mathrm{pH}$, dissolved oxygen, $\mathrm{N}$ and $\mathrm{P}$ records did not depart from natural conditions, nitrate and ammonium levels could be modeled as a function of a conservative variable, salinity, according to the following equations, and no relevant hydro-morphological alterations were identified throughout the estuary.

$$
N=1.6415 e^{-0.059 S}
$$

where $N$ is nitrates $(\mathrm{mg} / \mathrm{L})$ and $S$ is salinity (psu)

$$
A=0.1052 e^{-0.052 S}
$$

where $A$ is ammonium $(\mathrm{mg} / \mathrm{L})$

The above results were also coherent with the "high" classification for the physicochemical indicators obtained in the previous assessment conducted by CHMS, which contributed to the overall "good" classification of ecological status for the estuary (CHMS, 2013). APA (2012) in turn assigned good physicochemical status to all waterbodies but hydromorphological status ranged from high to moderate (see Table 1).

In contrast, conflicting classifications of status were obtained by using the indices of benthic invertebrates (M-AMBI, P-BAT; for discussion on these indices see Pinto et al., 2009). The classifications of status of the Minho estuary water bodies derived from those community indices covered the entire possible range of variability, from high to bad, and the same water body (ES260/PT16) was classified from high to poor depending on the assessment. As a result in the next cycle of assessment the hydrographic authority classified the estuary as in bad ecological status (CHMS, 2015) and remarked a trend toward decreasing quality that in fact is based only on the conflicting results of the benthic invertebrate indices shown in Table 1.

Seasonal and microgeographical variability certainly contributed to the heterogeneity of results. For example, the TMP results demonstrated that neighbor sites within the same water body may produce results for $\mathrm{M}$-AMBI from moderate to bad. Seasonal variability was evident in fish community richness, and sampling at the period of maximum richness, in which the classification obtained for three of the water bodies is "good" and for the most inner one is "moderate," was advised (Team Minho, 2013). Nevertheless, the most debatable issue was setting reference values and class boundaries. For benthic invertebrates, some assessments used fixed reference values whilst others adopted salinity dependent values. Since, salinity may vary with tide from 0 to $30 \mathrm{psu}$ in a single station, maximum values corresponding to high tide where considered more informative. Also there were discrepancies in the class boundaries for community indices. For example the vital limit between good 
TABLE 1 | Classification of ecological and chemical status of the water bodies from the international Minho estuary conducted by the Spanish administration (CHMS), the Portuguese administration (APA), and the international Team Minho Project (TMP).

\begin{tabular}{|c|c|c|c|c|c|c|c|}
\hline Water body Name/type & TMP type & $\begin{array}{l}\text { Ecological status } \\
\text { (CHMS, 2013) }\end{array}$ & $\begin{array}{l}\text { Ecological status (APA, } \\
\text { 2012) }\end{array}$ & $\begin{array}{l}\text { Ecol. Status } \\
\text { (Team Minho, } \\
\text { 2013) }\end{array}$ & $\begin{array}{l}\text { Ch. Status } \\
\text { (CHMS, } \\
\text { 2015) }\end{array}$ & $\begin{array}{l}\text { Ch. Status } \\
\text { (APA, 2012) }\end{array}$ & $\begin{array}{l}\text { Ch. Status } \\
\text { (Team } \\
\text { Minho, } \\
\text { 2013) }\end{array}$ \\
\hline ES240; PT23 (Type 8 IPH) & Marine estuary (Type 9 IPH) & $\begin{array}{l}\text { Not defined } \\
\text { (Phy:H, FQ:H) }\end{array}$ & $\begin{array}{l}\text { Bad } \\
\left(\text { Bio:B }^{(a)}, F Q: G, H M: M\right)\end{array}$ & $\begin{array}{l}\text { Bad } \\
\text { (Inv: B, Fish: G) }\end{array}$ & Good & $\begin{array}{l}\text { Less than } \\
\text { good (b) }\end{array}$ & Good \\
\hline ES250; PT18 (Type 8 IPH) & Fluvial estuary (Type $8 \mathrm{IPH}$ ) & Not defined & $\begin{array}{l}\text { Moderate } \\
\text { (Bio:M, FQ:G, HM:M) }\end{array}$ & $\begin{array}{l}\text { Moderate } \\
\text { (Inv: M, Fish: G) }\end{array}$ & Good & Good & Good \\
\hline ES260; PT16 (Type 8 IPH) & $\begin{array}{l}\text { Main silicic } \\
\text { Cantabrian-Atlantic fluvial } \\
\text { axis (Type } 28 \text { IPH) }\end{array}$ & $\begin{array}{l}\text { Good } \\
\text { (Phy:H, Inv: H, FQ:H, } \\
\text { SC: G) }\end{array}$ & $\begin{array}{l}\text { Good } \\
\text { (Bio: G, FQ:G, HM: H) }\end{array}$ & (Inv: P, Fish: G) & Good & Good & Good \\
\hline ES270; PT14 (Type 8 IPH) & & Not defined & $\begin{array}{l}\text { Good } \\
\text { (Bio:H, FQ:G, HM: H) }\end{array}$ & $\begin{array}{l}\text { Moderate } \\
\text { (Inv: M, Fish: M) }\end{array}$ & Good & Good & Good \\
\hline
\end{tabular}

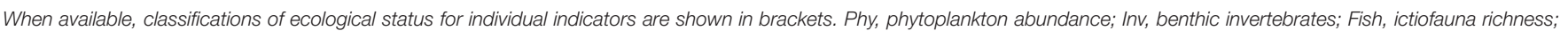

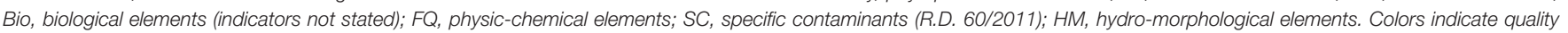
status as follows: red "bad," orange "poor," yellow "moderate," green "good," and blue "high" (as in Figure 2A).

(a) Responsible parameter: benthic invertebrates.

(b) Responsible parameter: nonylphenol.

(acceptable) and moderate (unacceptable) was taken as $58 \%$ of reference in some assessments and $53 \%$ in others.

It is still difficult to explain the disparity of benthic community results obtained in the different assessments. Community indices based on the classification of the species into groups of tolerance to organic enrichment (e.g., saprobic index) have been successfully applied to evaluate the quality of freshwater streams since the beginning of the Twentieth century. In marine environments, Reish (1955) was the first to report that certain polychaete taxa proliferated in organically polluted marine sediments, eventually causing an unbalance in the composition of the community. This unbalance can be quantified by the classical species richness (Margalef, 1958) or diversity (Shannon and Weaver, 1949) indices. But attempts to extend the saprobic index approach to estuarine and coastal ecosystems faced the fact that in seawater, unlike freshwater streams, the community composition is strongly determined by natural factors such as depth, salinity and bottom texture, among others. These factors vary also micro-geographically, within a given water body. Pearson and Rosenberg (1978) after a comprehensive review on the effects of organic pollution on marine benthic communities, proposed their well-known paradigm according to which anthropogenic organic enrichment eventually triggers a peak of abundance of a few opportunistic species (typically polychaetes such as Capitella and Scolelepis) that causes a decrease in the diversity of macrofaunal species. Subsequent applications of this paradigm have somewhat neglected the original observation that the peak of opportunists that unbalance the community takes place at high levels of impact only, and that species richness and diversity increase with moderate inputs of organic matter (reviewed by Gray, 1989). On the other hand, changes in the community structure identify an anthropogenic alteration a posteriori, and they are not useful as a preventive tool. Gray (1989) concluded that significant reductions in diversity take place quite late in the sequence of events triggered by anthropogenic environmental stress.

The emerging picture was that too many arbitrary values were needed for the current methodology of assessment based on multiple univariate elements. Concerning benthic indices, the adscription of species to tolerance groups is also debatable (Sampaio et al., 2011), and different indices present the same species classified in different groups of tolerance (Marín-Guirao et al., 2005). Furthermore, the variability in the PearsonRosenberg paradigm-based indices within a station and site has been demonstrated to be as large as that between stations and sites (Quintino et al., 2006).

In conclusion, the current scheme of water quality assessment should take a more holistic approach, seeking solid grounds on the ecological theory that states the hierarchical and dynamic nature of ecosystems. The classification of aquatic ecosystems into discrete, and necessarily arbitrary, categories of ecological status can best be achieved by combining observations extracted at different levels of biological organization, from molecular biomarkers to community traits, with explicative physicochemical and hydromorphological elements, and by using non-metric multivariate analysis techniques.

\section{AUTHOR CONTRIBUTIONS}

The author confirms being the sole contributor of this work and approved it for publication.

\section{ACKNOWLEDGMENTS}

This work was funded by Research Projects CTM2013-48194-C33-R and PCIN-2015-187-C03-03, from the Spanish MINECO, and by 0543-TEAM-MINO-1 E, from POCTEP and the European Regional Development Fund (European Commission). 


\section{REFERENCES}

Allan, I. J., Vrana, B., Greenwood, R., Mills, G. A., Roig, B., and Gonzalez, C. (2006). A "toolbox" for biological and chemical monitoring requirements for the European Union's Water Framework Directive. Talanta 69, 302-322. doi: 10.1016/j.talanta.2005.09.043

APA (2012). Plano de Gestão da Região Hidrográfica do Minho e Lima (RH1). Lisboa: Agência Portuguesa do Ambiente. Available online at: http://www. apambiente.pt/?ref=16\&subref=7\&sub2ref=9\&sub3ref=834\#pgbh-tabela last visit: 12/01/2016.

Arkema, K. K., Abramson, S. C., and Dewsbury, B. M. (2006). Marine ecosystembased management: from characterization to implementation. Front. Ecol. Environ. 4, 525-532. doi: 10.1890/1540-9295(2006)4[525:MEMFCT]2.0.CO;2

Beiras, R., and Durán, I. (2014). Objective classification of ecological status in marine water bodies using ecotoxicological information and multivariate analysis. Environ. Sci. Pollut. Res. 21, 13291-13301. doi: 10.1007/s11356-0132186-8

Burgeot, T., Bocquené, G., Pingray, G., Godefroy, D., Legrand, J., Dimeet, J., et al. (1994). Monitoring biological effects of contamination in marine fish along French coasts by measurement of ethoxyresorufin-O-deethylase activity. Ecotoxicol. Environ. Safety 29, 131-147. doi: 10.1016/0147-6513(94)90015-9

CBD (2016). Available online at: https://www.cbd.int/ecosystem/ last visit: $12 / 01 / 2016$

CHMS (2013). Plan Hidrológico de la parte española de la Demarcación Hidrográfica Miño-Sil. Confederación Hidrográfica Miño-Sil, Ourense.

CHMS (2015). Plan Hidrológico de la parte española de la Demarcación Hidrográfica Miño-Sil (2015-2021). Confederación Hidrográfica Miño-Sil, Ourense.

Christie, D. R. (2006). Implementing an Ecosystem-Approach to Ocean Management: An Assessment of Current Regional Governance Models. 16 Duke Environmental Law \& Policy Forum 117-142 (Spring 2006). Available online at: http://scholarship.law.duke.edu/delpf/vol16/iss2/1 last visit: 12/01/2016.

Coquery, M., Morin, A., Bécue, A., and Lepot, B. (2005). Priority substances of the European water framework directive: analytical challenges in monitoring water quality. Trends Anal. Chem. 24, 117-127. doi: 10.1016/j.trac.2004. 11.004

Costanza, R., d'Arge, R., de Groot, R., Farber, S., Grasso, M., Hannon, B., et al. (1997). The value of the world's ecosystem services and natural capital. Nature $387,253-260$.

Elliot, M., Burdon, D., Hemingway, K. L., and Apitz, S. (2007). Estuarine, coastal and marine ecosystem restoration: confusing management and science -a revision of concepts. Estuarine Coastal Shelf Sci. 74, 349-366. doi: 10.1016/j.ecss.2007.05.034

European Environment Agency (2012). European Waters - Assessment of Status and Pressures. Copenhagen. EEA Report No 8/2012. ISSN 1725-9177.

Gotelli, N. J., and Ellison, A. M. (2004). A Primer of Ecological Statistics. Sunderland, MA: Sinauer.

Gray, J. S. (1989). Effects of environmental stress on species rich assemblages. Biol. J. Linn. Soc. 37, 19-32. doi: 10.1111/j.1095-8312.1989.tb02003.x

Kimbrough, K. L., Johnson, W. E., Lauenstein, G. G., Christensen, J. D., and Apeti, D. A. (2008). An Assessment of Two Decades of Contaminant Monitoring in the Nation's Coastal Zone. Silver Spring, MD: NOAA Technical Memorandum NOS NCCOS 74.

Landis, W. G., Matthews, R. A., and Matthews, G. B. (1997). Design and analysis of multispecies toxicity tests for pesticide registration. Ecol. Appl. 7, 1111-1116. doi: 10.1890/1051-0761(1997)007[1111:DAAOMT]2.0.CO;2

Livingstone, D. R. (1991). Organic xenobiotic metabolism in marine invertebrates. Adv. Comp. Environ. Phys. 7, 45-185. doi: 10.1007/978-3-642-75897-3_2

Margalef, R. (1958). Information theory in ecology. Gen. Syst. 3, 36-71.

Marín-Guirao, L., Cesar, A., Marín, A., Lloret, J., and Vita, R. (2005). Establishing the ecological quality status of soft-bottom mining-impacted coastal water bodies in the scope of the Water Framework Directive. Mar. Pollut. Bull. 50, 374-387. doi: 10.1016/j.marpolbul.2004.11.019

Martínez-Haro, M., Beiras, R., Bellas, J., Capela, R., Coelho, J. P., Lopes, I., et al. (2015). A review on the ecological quality status assessment in aquaticsystems using community based indicators and ecotoxicologicaltools: what might be the added value of their combination? Ecol. Indic. 48, 8-16. doi: 10.1016/j.ecolind.2014.07.024
Matthews, G., Matthews, R., and Landis, W. (1995). Nonmetric conceptual clustering in ecology and ecotoxicology. Artif. Intell. App. 9, 41-48.

Morishita, J. (2008). What is the ecosystem approach for fisheries management? Mar. Policy 32, 19-26. doi: 10.1016/j.marpol.2007. 04.004

Odum, E. P. (1985). Trends in stressed ecosystems. Bioscience 35, 419-422. doi: $10.2307 / 1310021$

Odum, E. P. (1987). Reduced-input agriculture reduces non-point pollution. J. Soil Water Conserv. 42, 412-414.

Odum, E. P. (1989). Input management of production systems. Science 243, 177-182.

Odum, E. P., and Cooley, J. L. (1980). "Ecosystem profile analysis and performance curves as tools for assessing environmental impact," in Biological Evaluation of Environmental Impacts: The Proceedings of a Symposium. Council on Environmental Quality and Office of Biological Services; Fish and Wildlife Service. USDI. FWS/OBS-80/26. Washington, DC: US Government Printing Office, 84-102.

OSPAR Commission (1997). JAMP Guidelines for General Biological Effects Monitoring (OSPAR Agreement 1997-7). London: OSPAR Convention for the protection of the marine environment of the North-East Atlantic.

Pearson, T. H., and Rosenberg, R. (1978). Macrobenthic succession in relation to organic enrichment and pollution of the marine environment. Oceanogr. Mar. Biol. Ann. Rev. 16, 229-311.

Petrulis, J. R., and Bunce, N. J. (1999). Competitive inhibition by inducer as a confounding factor in the use of the ethoxyresorufin-O-deethylase (EROD) assay to estimate exposure to dioxin-like compounds. Toxicol. Lett. 105, 251-260. doi: 10.1016/S0378-4274(99)00005-3

Pinto, R., Patrício, J., Baeta, A., Fath, B. D., Neto, J. M., and Marques, J. C. (2009). Review and evaluation of estuarine biotic indices to assess benthic condition. Ecol. Indicators 9, 1-25. doi: 10.1016/j.ecolind.2008. 01.005

Quintino, V., Elliot, M., and Rodrigues, A. M. (2006). The derivation, performance and role of the univariate and multivariate indicators of benthic change: Case studies at differing spatial scales. J. Exp. Mar. Biol. Ecol. 330, 368-382. doi: 10.1016/j.jembe.2005.12.040

Reish, D. J. (1955). The relation of polychaetous annelids to harbour pollution. Public Health Rep. 70, 1168-1174. doi: 10.2307/4589315

Sampaio, L., Rodrigues, A. M., and Quintino, V. (2011). Can biotic indices detect mild organic enrichment of the seafloor? Ecol. Indic. 11, 1235-1244. doi: 10.1016/j.ecolind.2011.01.001

Sanchez, W., and Porcher, J.-M. (2009). Fish biomarkers for environmental monitoring within the Water Framework Directive of the European Union. Trends Anal. Chem. 28, 150-158. doi: 10.1016/j.trac.2008.10.012

Schei, P. J. (1999). Chairman's Report. The Norway/UN Conference on the Ecosystem Approach for Sustainable Use of Biological Diversity. Trondheim.

Shannon, C. E., and Weaver, W. (1949). The Mathematical Theory of Communication. Chicago, IL: University of Illinois Press.

Team Minho (2013). Resultados de los Valores Limite que Identifican la Frontera Entre el Estado Ecológico Moderado y Bueno. Entregable Actividad 2; E.2. Available online at: http://www.team-minho.eu/index.php/gl/documentacion/ documentacion/category/6-entregables last visit: 12/01/2016.

Tett, P., Gowen, R. J., Painting, S. J., Elliott, M., Forster, R., Mills, D., et al. (2013). Framework for understanding marine ecosystem health. Mar. Ecol. Prog. Ser. 494, 1-27. doi: 10.3354/meps10539

Vogt, K. A., Gordon, J. C., Wargo, J. P., Vogt, D. J., Asbjornsen, H., Palmiotto, P. A., et al. (1997). Ecosystems. Balancing Science with Management. New York, NY: Springer.

Conflict of Interest Statement: The author declares that the research was conducted in the absence of any commercial or financial relationships that could be construed as a potential conflict of interest.

Copyright (C) 2016 Beiras. This is an open-access article distributed under the terms of the Creative Commons Attribution License (CC BY). The use, distribution or reproduction in other forums is permitted, provided the original author(s) or licensor are credited and that the original publication in this journal is cited, in accordance with accepted academic practice. No use, distribution or reproduction is permitted which does not comply with these terms. 